\title{
Effect of Different Nitrogen and Weeding Levels on Vegetative Growth of Five Cultivars of Corn ( Zea mays L.)
}

\author{
I.A.Radma ${ }^{1}$, Y.M.I.Dagash ${ }^{2, *}$ \\ ${ }^{1}$ Ministry of Agriculture and Natural Resources, Gezira State, Sudan \\ ${ }^{2}$ Sudan University of Science and Technology (SUSTECH), Sudan \\ *Corresponding Author: dagash501@yahoo.com
}

Copyright (C) 2013 Horizon Research Publishing All rights reserved.

\begin{abstract}
Field experiments were conducted in the Demonstration Farm of Mohammed Osman Salih ( Blue Nile North of Gezira state / ElBagair area) for the two consecutive seasons ( summer $2007 / 2008$ and $2008 / 2009$ to study the effect of different Nitrogen and Weeding Levels on Vegetative growth of Five Cultivars of Zea mays. The treatments used consisted of three levels of nitrogen control (N0), $86 \mathrm{~kg} \mathrm{~N} / \mathrm{ha} \mathrm{(N1),} 129 \mathrm{~kg} \mathrm{~N} / \mathrm{ha}$ (N2), two levels of weeding non-weed control (W0), weeding (W1) and five cultivars, open pollinated Giza-2 (V1) , Var113 (V2), Hudiba-1 (V3) and Hybrid cultivars, Hycorn-90 (V4) and Hycorn-675 (V5). The 30 factorial treatments were executed in randomized complete block design, with four replications. The results obtained showed that nitrogen fertilizer had a significant effect on growth of maize cultivars, particularly plant height, leaves number and dry weight of plant. The results from these experiments showed that hybrid cultivars maize efficiently utilized nitrogen without weeding better than the open cultivars except Giza-2. The results obtained showed negligible differences between the two seasons for vegetative growth. This justifies growing maize in summer with $129 \mathrm{~kg} / \mathrm{ha}$ nitrogen and good cultivation.
\end{abstract}

Keyword Cultivar, Growth, Nitrogen, Weeding

\section{Introduction}

Maize ( Zea mays L.) or Corn, is the most important cereal crop in sub-Saharan Africa and with rice and wheat, comprise the three most important cereal crops in the world. Maize is high yielding, easy to process, readily digested. It is also a versatile crop, growing across a range of agroecological zone. Every part of maize plant has economic value: the grain, leaves, stalk, tassel, and cob can all be used to produce a large variety of food and non-food products. In industrialized countries, maize is largely used as livestock feed and as a raw material for industrial products, while in developing courtiers it is mainly used for human consumption. In sub-Saharan Africa, maize is a staple food for $50 \%$ of the population. It is important source of carbohydrate, protein, vitamin B, and minerals. Green maize (fresh on the cob) is eaten boiled, playing an important role in filling the hunger gap (CIMMYT, 1994 and USDA, 2009). Maize (Zea mays L, ) is grown on approximately 140 million hectares (M/ha) worldwide: $97 \mathrm{M} / \mathrm{ha}$ in developing countries, $34 \mathrm{M} / \mathrm{ha}$ in the high income countries, and $9 \mathrm{M} / \mathrm{ha}$ in the Eastern Europe and the former Soviet Union (http://www.c.1994). Maize is a staple food for several hundred million people in the developing world. The average inhabitant of Eastern and Southern Africa consumes about $80 \mathrm{~kg}$ of maize each year; while in Mexico, Central America, and the Caribbean he consumes about $170 \mathrm{~kg}$. Annual per capita maize utilization averages $100 \mathrm{~kg}$ in East Asia and more than $190 \mathrm{~kg}$ in the southern cone of South America, largely as animals feed in both cases. Unfortunately, developing countries do not produce enough maize to meet their needs and must therefore import approximately 30 million tons of maize annually. Use of improved cultivars and management practices should help increase maize yield and reduce imports in developing countries. (http:// www.c.2009). Maize or corn as a world Crop is grown in various countries. The crop is widely used as a food crop in many parts of the world especially in the tropical and subtropical countries. Maize is rich in starch (carbohydrates) with an average of about $70 \%$, but low in protein (about $9.5 \%$ ). The oil is concentrated mainly in the germ with an average of $4 \%$ of kernel weight. The composition of other components of the kernel is $1.4 \%$ sugars, 2.3 crude fiber and $1.4 \%$ ash. Maize seed enters also in livestock feeds, and in other industrial purposes as in the case of glucose, starch and edible oil industries. One of the causes of low production could be attributed to high infestation of weeds. Because of acute shortage of labor and frequent monsoon rain during the early growth period of maize, hand weeding or mechanical 
weeding operations are usually delayed or left altogether. In such situations, herbicides offer the most practical, effective and economical method of weed control and increase crop yield.Weeds are one of the most important factors in maize production. They cause significantly yield losses worldwide with an average of $12.8 \%$ despite weed control application and $29.2 \%$ in case of no weed control (Oerke and Steiner. 1996). Therefore, weed control is an important management practice for maize production and should be carried out to ensure optimum grain yield. Weed control in maize is carried out by mechanical and/ or chemical methods. Weed between plants rows are removed generally by mechanical cultivation. While weeds on the rows are controlled by hand hoeing or by herbicides, and both methods are effective in controlling weeds. In Sudan, Maize utilization as a human food for making bread was limited, where most of the produce is consumed as roasted kernels or in mixing with wheat to make bread. The environmental conditions in the Sudan are generally favorable for maize production. Old statistics showed that the crop used to be produced in various ecological zones (Arab, O. 2006 and AOAD, 1986). The main objective of thisresearch is to study the effects of the nitrogen and weeding on vegetative growth of a number of maize genotypes and to select the best cultivar for the prevailing conditions.

\section{Materials and Methods}

The experiment was conducted for two consecutive summer seasons of 2007/2008 and 2008/2009. they were conducted in the farms of Osman Salih ElBagir area (North of Gezira state. Sudan) latitude 15-22N and longitude 32-46 E. on sandy clay loam soil. The seeds consisted of open-pollinated cultivars (Geza-2, Hudeiba-1 and var-113) and hybrid cultivars (Hycorn-90 and Hycorn-675). The experiment was factorial in a randomized complete block design, with four replications. The treatments consisted of the five cultivars of maize (V1 = Geza-2, V2 = var-113, V3 $=$ Hudiba $-1, \mathrm{~V} 4=$ Hycorn-90, V5 = Hycorn-675. The three levels of nitrogen are:- $\mathrm{N} 0=($ control $)$ with no nitrogen , N1 ( $86 \mathrm{~kg} \mathrm{~N} / \mathrm{ha}), \mathrm{N} 2(129 \mathrm{~kg} \mathrm{~N} / \mathrm{ha})$ : and the two levels of weed are : W0 ( control ) with no weed , W1 = weeding . Measurements of growth attributes were taken approximately every two weeks, starting 30 days from sowing-from each plot, six plants were selected at random from the two inner ridges and after leaving one meter at each end of the plot. The selected plants were tagged and the observations were made on them. The plant height was measured at 30, 45 and 60 days from sowing in each subplot. The measurements were made from the base of the youngest leaf to the top of the young leaf. Then the mean plant height was recorded for each plot. The six plants used for the measurement of plant height were also used for the count of number of leaves per plant where the average numbers of leaves were recorded. The six plants of each plot were cut at 120 days from sowing and sun-dried then weighed and the average dry weight per plant was recorded. The six plants of each plot were cut at 120 days from sowing and sun-dried then weighed and the average dry weight per plant was recorded. Data collected from the different treatment were subjected to analysis of variance (ANOVA) appropriate for randomized complete block design (Gomez and Gomez, 1984).The means were separated using the least significant difference (LSD) and Duncan Multiple Range Test (DMRT).

\section{Results}

From the analysis of variance(table1,2), after30 days it was clear that there were significant $(\mathrm{P}=0.01)$ differences in number of leaves per plant between the levels of nitrogen and also between the two levels of weed. The differences between the cultivars and all interaction were not significant in the first and second seasons. After 45 days, it was clear that there were significant $(\mathrm{P}=0.01)$ differences in number of leaves per plant between the different levels of nitrogen. The application of $86 \mathrm{~kg} \mathrm{~N} / \mathrm{hg}$ gave $25 \%, 8 \%$ significantly higher number of leaves over control respectively, whereas the application of $129 \mathrm{~kg} \mathrm{~N} / \mathrm{hg}$ increased the number of leaves over control by $42 \%$. On the other hand, there were no significant differences in the leaf number between the application of 86 and $129 \mathrm{~kg} \mathrm{~N} / \mathrm{hg}$. Also, in the first one there were significant differences between cultivars, where cultivar Giza-2, HyCorn90 and HyCorn-675 gave significantly higher leaf Number per plant than the cultivars var-113 and Hudiba-1, which were not significantly different from each other. The difference between the two weeding treatments was significant. While in the second season there were significant differences between the cultivars, where Hycorn 90 gave significantly higher leaf number per plant than the cultivars Giza-2, var-113, Hudiba-1 and Hycorn 675, which were not significantly different from each other. The difference between the two levels of weeding was significant and weeding gave $20 \%$ higher leaf number over control which were not significantly different from each other. On the other hand the interaction of all treatment levels had significant effect . After 60 days, completely different pattern in the application of $86 \mathrm{~kg} \mathrm{~N} / \mathrm{ha}$ which gave $29 \%$, $27 \%$ significantly higher leaf number over the control, whereas the application of $129 \mathrm{~kg} \mathrm{~N} / \mathrm{ha}$ increased the number of leaves over the control by $36 \%, 40 \%$ respectively. On the other hand, there were significant differences in leaf number per plant between the application of 86 and $129 \mathrm{~kg} \mathrm{~N} / \mathrm{ha}$. In the first season there was significant effect of cultivars, and weeding on interaction number of leaves but in the second there was no significant differences. From the statistical analysis(table1,2), after 30 days it was clear that there were significant differences in plant height between the levels of nitrogen. The application of $86 \mathrm{~kg} \mathrm{~N} / \mathrm{ha}$ gave $21 \%, 17 \%$ significantly greater plant height over control, whereas the application of $129 \mathrm{~kg} \mathrm{~N} / \mathrm{ha}$ increased plant height over control by $29 \%, 37 \%$ respectively. There were significant differences between cultivars, where HyCorn-675 and 
var-113 gave significantly higher plants than the cultivars Giza-2, Hudiba -1 and HyCorn -90, which were also significantly different from each other in the first season but in the second, Hycorn -675 gave significantly higher plants than other cultivars. The effect of weeding on plant height was significant. Also, effect of interaction was significant in the all . After 45 days, There were significant differences in plant height between the levels of nitrogen .The application of $86 \mathrm{~kg} \mathrm{~N} /$ ha gave $7 \%, 5 \%$ significantly greater plant height over control, whereas the application of $129 \mathrm{~kg} \mathrm{~N} / \mathrm{ha}$ increased the plant height over the control by $26 \%, 13 \%$ respectively. On the other hand, in the first one there were no significant differences in plant height between the application of $86 \mathrm{~kg} \mathrm{~N} / \mathrm{ha}$ and $129 \mathrm{~kg} \mathrm{~N} / \mathrm{ha}$, and found significant difference in the second. First season, there were significant differences between cultivars, where the cultivars HyCorn-90 and HyCorn -675 gave significantly greater plant height than cultivars Giza-2, var-113 and Hudiba-1, which were significantly different from each other. Also, in the second there were significant differences between cultivars, where Giza-2 gave higher plant than other, which were no significantly different from each other The differences between the levels of weed were highly significant. After 60 days there were significant differences in plant height between the levels of nitrogen. The application of $86 \mathrm{~kg} \mathrm{~N} / \mathrm{ha}$ gave $19 \%, 6 \%$ significantly higher plants over control, where the application of $129 \mathrm{~kg} \mathrm{~N} / \mathrm{ha}$ increased the plant height over the control by $37 \%, 19 \%$ respectively. On the other hand, there were significant differences in plant height between the application of $86 \mathrm{~kg} \mathrm{~N} / \mathrm{ha}$ and $129 \mathrm{~kg} \mathrm{~N} / \mathrm{ha}$. There were significant differences between cultivars, where cultivars HyCorn-675 gave significantly greater plant height per plant than the cultivars Giza-2, var-113, Hudiba-1 and HyCorn-90, which were not significantly different from each other in both seasons. The differences between the two levels of weeding were significant . Interaction of treatments was also significant.

Analysis of variance(table1,2) show clear significant $(\mathrm{P}=$ 0.01 ) differences in dry weight between the levels of nitrogen. The application of $86 \mathrm{~kg} \mathrm{~N} / \mathrm{ha}$ gave $20 \%, 26 \%$ significantly higher dry weight over control, whereas the application of $129 \mathrm{~kg} \mathrm{~N} / \mathrm{ha}$ increased the dry weight per plant over the control by $27 \%, 30 \%$ respectively. Also, in the two season there were significant $(\mathrm{P}=0.01)$ differences between cultivars, where cultivar HyCorn-90 gave significantly higher dry weight than the cultivars Giza-2, var.113, Hudiba-1 and Hycorn-675, which were significantly different from each other. The interaction between treatments and weeding were also significant.
The present study showed that nitrogen had significant effect on number of leaves per plant and plant height. Both $\mathrm{N} 1$ and N2 gave significant increase in plant growth in comparison to the control (N0). From the result obtained for both season it was clear that all vegetative growth parameters increased with increasing levels of nitrogen. Also cultivars showed significant differences in the plant height. In this connection , Turkhede and Jajendra ( 1978); Mock and Henghin (1976); Peter et al. (1988); Hattab et al. (1980) and Omara (1989) reported similar result on the effects of nitrogen on plant height, where they attributed the result to the fact that nitrogen promotes plant growth. With regards to the number of leaves per plant, Reddy and Hussein (1969); Waston (1952) and Zahir et al. (2007); Arshed et al. (1994); Zahir et al. (2000) found similar result. Also it was reported by Yanusa et al. (1991) that taller cultivars gave greater number of leaves than the dwarf cultivars, which agree with our results where Giza-2 and Hycorn-675 gave taller plants, but Giza-2 and Hycorn -90 gave greater number of leaves. Weed control resulted in significantly higher leaf number and plant height in both seasons than the unweeded control. Similar results were obtained by Kumar (1973); Knezevic et al. (2002); (Rajcan and Swanton, 2001) and Rubin (1996). Also Rai (1965) reported that weed control resulted greater number of leaves when weeds were reduced at different growth stages. This has been also reported for other crops such as potato and maize ( Eghtedari Naeini, 1996) ; Javanbakht and Hesar, 1996). Emergence time of weeds influences the critical period for weed control (Zimdahl, 1987; Weaver et al., 1992; Mesbah et al., 1994; Ghadiri, 1996 ). In this study, maize growth was not significant with nitrogen fertilizer, non-weeding and the interaction in both seasons. Similar results were obtained by Thomas and Allison (1975); Marais (1985); Twomlow et al. (1997). Steel et al. (1997); Akobundu (1987) and Shumb (1988) who showed that the interaction effects of weed distance from the maize row on maize development and grain yield was not significantly affected by the time of weed removal. Weeding had significant effect on dry weight and in general weed control gave higher dry weight in both seasons. This result is confirmed by Teton-Kagho and Gardner (1988). Nitrogen application generally increased dry weight/plant and the increase reached significant levels at later stages of growth in both seasons. Such effects could be attributed to enhancement of vegetative growth and dry weight production by nitrogen. The interaction of $\mathrm{N}$ with weeding had significant effect on dry weight (at early stages at over 60 days from sowing) in the second season. It is well known that the combined effect of nitrogen and weeding is greater than individual effect of each treatment by itself.

\section{Discussions}


Table 1. F-value of the measured variables for interaction of cultivar weeding and fertilizer treatment 2007/08 season

\begin{tabular}{|c|c|c|c|c|c|c|c|c|}
\hline $\begin{array}{l}\text { Suorce of } \\
\text { variation }\end{array}$ & d.f. & $\begin{array}{l}\text { No. of leaves } \\
\text { at } 30 \text { days }\end{array}$ & $\begin{array}{l}\text { No. of leaves } \\
\text { at } 45 \text { days }\end{array}$ & $\begin{array}{l}\text { No. of leaves } \\
\text { at } 60 \text { days }\end{array}$ & $\begin{array}{l}\text { Plant height } \\
\text { at } 30 \text { days } \\
(\mathrm{cm})\end{array}$ & $\begin{array}{l}\text { Plant height at } \\
45 \text { days }(\mathrm{cm})\end{array}$ & $\begin{array}{l}\text { Plant height at } \\
60 \text { days }(\mathrm{cm})\end{array}$ & $\begin{array}{l}\text { Dry weight per } \\
\text { plant (gm) }\end{array}$ \\
\hline Variety (V) & 4 & $4.73^{*}$ & $16.70 * *$ & $48.32 * *$ & $24.80 * *$ & $152.50 * *$ & $23.90 *$ & $36.28 * *$ \\
\hline Nitrogen $(\mathrm{N})$ & 2 & $155.25 * *$ & $192.00 * *$ & $348.70 * *$ & $566.60 * *$ & $2314.12 * *$ & $308.03 * *$ & $656.70 * *$ \\
\hline Weeding (W) & 1 & $40.91 * *$ & $301.45 * *$ & $213.41 * *$ & $520.30 * *$ & $354.80 * *$ & $3553.70 * *$ & $117.60 * *$ \\
\hline VXN & 8 & $4.29^{*}$ & $0.58 \mathrm{NS}$ & $1.56 \mathrm{NS}$ & $13.41 * *$ & $110.50 * *$ & $4.75 \mathrm{NS}$ & $117.62 * *$ \\
\hline VXW & 4 & $6.28 * *$ & $0.81 * *$ & $4.94 *$ & $24.57 * *$ & $18.57 * *$ & $8.59 *$ & $27.89 *$ \\
\hline NXW & 2 & $1.09 *$ & $8.02 *$ & $6.99 *$ & $5.22 *$ & $13.60^{*}$ & $4.30 \mathrm{NS}$ & $20.84 *$ \\
\hline VXNXW & 8 & $3.59 \mathrm{NS}$ & $4.32 * *$ & $6.56^{* *}$ & $12.00^{*}$ & $11.14^{*}$ & $3.34 \mathrm{NS}$ & $98.44 * *$ \\
\hline MS Error & - & 1.19 & 0.90 & 1.09 & 2.47 & 5.90 & 29.26 & 43.93 \\
\hline $\mathrm{SE}(+-)$ & - & 0.32 & 0.27 & 0.30 & 0.45 & 0.70 & 1.56 & 1.91 \\
\hline LSD & - & 0.62 & 0.52 & 0.69 & 0.99 & 0.15 & 3.44 & 4.20 \\
\hline CV (\%) & - & $4.20 \%$ & $2.10 \%$ & $0.60 \%$ & $0.70 \%$ & $0.60 \%$ & $7.50 \%$ & $0.70 \%$ \\
\hline
\end{tabular}

NS $=$ not significant

*Significant (5\%)

**Highly significant $(1 \%)$

Table 2. F-value of the measured variables for interaction of cultivars weeding and fertilizer treatments 2008 / 09 season

\begin{tabular}{|c|c|c|c|c|c|c|c|c|}
\hline $\begin{array}{l}\text { Suorce of } \\
\text { variation }\end{array}$ & d.f. & $\begin{array}{l}\text { No. of leaves } \\
\text { at } 30 \text { days }\end{array}$ & $\begin{array}{c}\text { No. of } \\
\text { leaves at } 45 \\
\text { days }\end{array}$ & $\begin{array}{c}\text { No. of } \\
\text { leaves at } 60 \\
\text { days }\end{array}$ & $\begin{array}{c}\text { Plant } \\
\text { height at } \\
30 \text { days } \\
(\mathrm{cm})\end{array}$ & $\begin{array}{c}\text { Plant } \\
\text { height at } \\
45 \text { days } \\
(\mathrm{cm})\end{array}$ & $\begin{array}{c}\text { Plant } \\
\text { height at } \\
60 \text { days } \\
(\mathrm{cm})\end{array}$ & $\begin{array}{c}\text { Dry weight per } \\
\text { plant (gm) }\end{array}$ \\
\hline Variety (V) & 4 & $21.33 *$ & $28.42 * *$ & $87.54 * *$ & $250.20 * *$ & $744.80 *$ & $877.40 * *$ & $25.22 *$ \\
\hline Nitrogen $(\mathrm{N})$ & 2 & $174.22 * *$ & $574.10^{* *}$ & $494.80 * *$ & $2557.40 * *$ & $655.02 * *$ & $3266.02 * *$ & $49.12 *$ \\
\hline Weeding (W) & 1 & $126.08 * *$ & $240.83 * *$ & $418.13 * *$ & $1620.70 * *$ & $5880.00^{* *}$ & $6134.70^{* *}$ & $80.03 * *$ \\
\hline VXN & 8 & $21.62 *$ & $17.18^{*}$ & $33.30^{*}$ & $128.76^{* *}$ & $114.56^{* *}$ & $337.56 * *$ & $6.38^{*}$ \\
\hline VXW & 4 & $14.47 *$ & $14.75^{*}$ & $14.12 *$ & $165.62 * *$ & $1203.80^{* *}$ & $375.50^{* *}$ & $10.21 *$ \\
\hline NXW & 2 & $6.65^{*}$ & $14.87^{*}$ & $62.06 * *$ & $154.20 * *$ & $1.25 \mathrm{NS}$ & $33.45 *$ & $2.11 \mathrm{NS}$ \\
\hline VXNXW & 8 & $14.18^{*}$ & $28.05^{* *}$ & $31.93 *$ & $167.63 * *$ & $82.17 *$ & $485.50^{* *}$ & $19.88^{*}$ \\
\hline MS Error & - & 1.19 & 1.19 & 0.96 & 21.36 & 3.57 & 89.85 & 2.34 \\
\hline $\mathrm{SE}(+-)$ & - & 0.32 & 0.32 & 0.28 & 1.02 & 0.55 & 2.74 & 0.44 \\
\hline LSD & - & 0.68 & 0.64 & 0.62 & 0.80 & 1.12 & 5.99 & 0.96 \\
\hline CV (\%) & - & $18.00 \%$ & $21.20 \%$ & $17.70 \%$ & $17.40 \%$ & $14.10 \%$ & $19.70 \%$ & $36.40 \%$ \\
\hline
\end{tabular}

$\mathrm{NS}=$ not significant

*Significant (5\%)

**Highly significant (1\%) 


\section{Conclusions}

In this study, $\mathrm{N}$ application to maize tended to improve vegetative growth. The response to $\mathrm{N}$ increased as level of $\mathrm{N}$ applied increased. Thus it is feasible to recommend $\mathrm{N}$ application to maize under similar conditions .This suggest, as mentioned earlier, that maize crop in this area can successfully be grown in the summer season in Northern, Gezira and similar areas in Sudan. The weed control used in this study failed to bring out clear differences in growth of maize. More weeding during crop growth is required in order to determine the optimum weed control for maize.. The experiment was conducted during summer in both seasons. Further studies are needed to compare summer growing with winter growing. The results from these experiments showed that hybrid maize (Hycorn-90 and Hycorn-675) efficiently utilized nitrogen better than the open pollinated (Hudiba-1andVar-113) with the exception of Giza-2.

\section{REFERENCES}

[1] Akobundu, I.O., 1987. Weed Science In The Tropics, Principles And Practices .John Wiley And Sons, Chichester, pp: 522.

[2] Aoad-1986 Morocco Primary Feasibility Study For Corn Production At Gezira Province (Arabic Issue). Arab Organization For Agricultural Development, 2006. Study For Corn Production. Khrtoum.Sudan (Arab Issue).

[3] Arnon, I., 1972. Crop production in dry regions. 2: systematic treatment of principal crops. Leonard Hill, London.

[4] Arshad, M., A. Hussain And M. Javed, 1994. Response Of Maize To Soil Applied L . Pgrsu Quart., 22: 17-18.

[5] Cimmyt., 1994. Cimmyt 1993/94 World Maize Facts And Trends. Maize Seed Industries, Revisited Emerging Roles Of The Public And Private Sector .Mexico, D.F. Cimmyt.Org-1994Htt:/Www./English/Docs/Tech-Pubs/Ope n-Pollinated/ Devmainseed.html.

[6] Eghtedari Naeini, A.R., 1996. Determination of critical period of weed control in maize at Bajgah and Koushkak regions in Fars province. M.Sc. Thesis. Shiraz University, Iran.

[7] Ghadiri, H., 1996. Concept and application of critical period of weed control. Collections of full papers of 4th Iranian crop production and breeding congress Isfahan, pp: 257-265.

[8] Hattab, H.S., M.A. Hussein, A.H. Hattab, M.S. Raouf and A.A. ElNomany, 1980. Growth analysis on maize plant in relation to seed yield as affected by nitrogen level. Yield Crop Abst., 32(12): 1036 Abst-9882.

[9] Http://www.bulbnrose, 2009. org./Heredity/Anderson/Ander son maize Breeding.htm.

[10] Http://www.Cimmyt.org. 1994 ./English/docs/tech-pups/open-pollination/devmainseed .htm.
[11] Javanbakht Hesar, M., 1996. Determination of critical period of weed control in maize at Bajgah region in Fars province, M.Sc. Thesis, Shiraz University.

[12] Kamaraswamy, R., 1973. A note on the availability of phosphorous with advancement of crop growth. Madras Agric. J. 60(5): 341-342.

[13] Kenezevic, S.Z., Sp.Evans. E.E. Blankenship, R.C. Van Acker And J.L. Lindqusit, 2002. Critical Period For Weed Control . The Concept And Data Analysis Weed Science, 50:773-786.

[14] Marais, J.N., 1985. Weed Competition In Maize With Reference To Peasant Fort Hare Papers 8:62 -82.

[15] Meshah, A., S.D. Miller, K.J. Fomstrom and D.E. Legg, 1994. Sugar beet-weed interactions. University of Wyoming.

[16] Mock, J.J and L.C. Heghin, 1976. Performance Of Maize Hybrids Grown In Conventional Row And Randomly Distributed Planting Patterns. Agronomy Journal, 68: 577-580.

[17] Oerke, E.C. And U. Steiner, 1996. Abschatzung Der Ertragsverluste In Maisandau. In:Ertragsverluste Und Pflanzenschutz Die Anbausituation Fur Die Wirtschafth Wichtigsten Kulturpflanzen- Germphytomedical Society Series, Band 6: 63-79. Eugen Ulmer Verlag. Stuttgart.

[18] Peter, J., V. Cerney and L. Hruska, 1988. Yield Formation In The Main Crops, pp: 167-178 New York: Elsevier.

[19] Yoshida, S. 1972.Physiological Aspects Of Crop Yield. Annual Review Of Plant Physiology, 23-437-464.

[20] Rajcan, I. and C.J. Swanton, 2001. Understading maize-weed competition: resource competition, light quality and the whole plant. Field crops Research, 71: 139-150.

[21] Rubin, B., 1996. Herbicide-resistant weeds. The inevitable phenomenon mechanism, distribution and

[22] significance. Zietschrift fur Torstenson Pflanzenkrankheiten under pflanzenschutz. Sonderheft XV. 17-32.

[23] Shumba, E.M., 1988 Maize Technology Research In Mangwende, A High Potential Communal Area Environment In Zimbabwe. Part 1. Developing A Research Genda. Cimmyt System News Latter 34:12-34.

[24] Steel, R.D.G., T.H. Torrie. And D.A. Dickey, 1997. Principles And Procedures Of Statics: A Biomefrical Apprach. 3rd Ed.Mc Graw- Hill, New York., pp: 666.

[25] Teton-Kagho, F. And F.P. Gardner, 1988. Response Of Maize To Plant Population Density. I. Canopy Development, Light Relationships, And Vegetative. Agron. J. 80: 930-935.

[26] Thomas, P.E.L. And J.C.S. Allison, 1975. Competition Between Maize And Rottboellia Exalta, Journal Of Agricultural; Science, Cambridge, 84: 305-312.

[27] Turkhede, B.B. and P. Rajendra, 1978. Effect of rate and timing of nitrogen application on hybrid sorghum. Indian J. Agron., 23(2): 209-212.

[28] Twomlow, S., C.R. Riches, And S. Mabasa, 1997. Weeding -Its Contribution To Aoil Water Conservation In Semi-Arid Maize Production. In: British Crop Protection Conference-Weeds, Brighton. Uk. pp: 185 -190. 
[29] Watson, D.J., 1952. The physiological basis of variation in yield. Advances and Agron., 4: 125-138.

[30] Yanusa, A.M., 1991. Growth and yield of maize genotypes during dry seasons in Northern Nigeria. 27(4): 397-405. Department of Crop Science, University of Maiduguri, PMB 1069, Nigeria.

[31] Zahir, Z.A., M.A.R. Malik And M. Arshad, 2000. Improving Crop Yield By The Application Of An Auxin Precursor.Ltrp.Pak.J. Biol, Sci., 3: 133-135.
[32] Zahir, Z.A.M., M.I. Naveed, H.S. Zafar, M. Rehman, Arshad And M. Khalid, 2007. A.Evalution Of Composed Organic Waste Enriched With Nitrogen And L.Tryptophan For Improving Growth And Yield Of Maize

[33] (Zea Mays ) Pak. J .Bot, 39(5): 1739-1749. Zimdahl, R.L., 1987. The concept and application of the critical weed. Free-period. In: weed management and agroecosystems: Ecological Approaches. (Eds. M.A. Altieri and M. Liebman). CRC Press, Inc. Florida, USA. pp: 145-155. 